\title{
Mind the gap: Australian local government reform and councillors' understandings of their roles
}

\section{Commonwealth Journal of Local Governance \\ Issue 19: December 2016}

http://epress.lib.uts.edu.au/ojs/index.php/cjlg

\section{Su Fei Tan}

University of Technology Sydney

Australia

\section{Alan Morris}

University of Technology Sydney

Australia

\section{Bligh Grant}

University of Technology Sydney

Australia
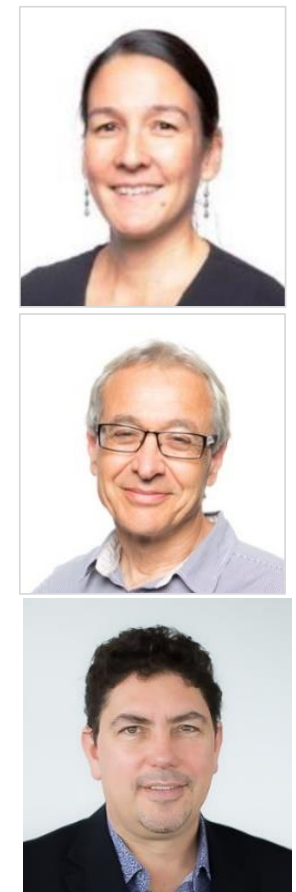

\begin{abstract}
Over the last two decades a feature of local government reforms globally has been the introduction of New Public Management (NPM). Under this broad approach to public administration there is an expectation that councillors play a greater strategic role and move away from involvement in day-today management. This research, carried out in the state of Victoria, Australia, examines councillors' understandings of their roles. Based on 17 in-depth interviews and two focus groups, we found that despite the evolving legislative requirements framing councillors as policymakers not managers, most councillors continued to seek involvement in the day-to-day management of councils. We argue that this gap may be linked to the diversity of views concerning the role of the councillor and the idea of representation and how both play out at the local level. It may also signal a lack of awareness as to how the legislatively inscribed role for councillors has changed over time.
\end{abstract}

Keywords: Councillor roles, local government leadership, local government reform, New Public Management (NPM), local representation

(c) 2016 Su Fei Tan, Alan Morris and Bligh Grant. This is an Open Access article distributed under the terms of the Creative Commons Attribution 4.0 Unported (CC BY 4.0) License (https://creativecommons.org/licenses/by/4.0/), allowing third parties to copy and redistribute the material in any medium or format and to remix, transform, and build upon the material for any purpose, even commercially, provided the original work is properly cited and states its license. 


\section{Introduction}

Across Australia local councils are de jure and de facto the level of government closest to communities (Grant and Dollery 2012). They deliver an increasingly broad range of services from critical infrastructure such as roads and sewage to community services such as sports and leisure facilities, libraries and child-care (Dollery et al. 2006). Local councils were first established in the mid-nineteenth century to help colonial administrations manage a rapidly growing population and increasingly dispersed settlements (Power et al. 1981; Sansom 2009, p. 10). The early activities of local governments saw an emphasis on public health and building regulation. In rural areas road construction was a central activity. Although local governments raised their own revenues through property taxes or rates, they operated under tight colonial control. The limited autonomy of local government historically has persisted into the contemporary period and, despite local government being recognised to varying degrees within state constitutions, at present state governments exercise considerable control over local government (see Brown 2008; Dollery et al. 2009; Grant and Dollery 2012). This has resulted in local government having a comparatively restricted range of functions, a narrow fiscal base and limited revenue overall. Only approximately $3.5 \%$ of all government revenue is raised by local government (Department of Infrastructure and Regional Development 2013, p. 10). These factors have limited local governments' focus to some services and local infrastructure. They do not control electricity, policing, education, hospitals, or (except in the City of Brisbane) public transport and their contribution to the provision of affordable housing is minimal, although variable across the particular jurisdictions (Beer et al. 2014).

Nevertheless, in addition to their service provision function, local government is viewed as the 'seat' of local democracy. Aulich (2005, p. 198) described Australian local government as "giv[ing] voice to local aspirations for decentralised governance" as well as providing "a mechanism for efficient delivery of services to local communities". Despite the particular characteristics of Australian local government, it can be fruitfully compared to its counterparts in a myriad of contexts internationally. For example, Barnett (2011, p. 275) described English local government " $a$ key instrument for the delivery of services whilst also attempting to represent recipients and defend local populations in their interactions and struggles with those services". More specifically, in the international literature as well as in Australia, elected representatives, i.e. councillors, have variously been described as workers, managers and policymakers; or as trustees, delegates and party soldiers; as member of a governing body and an elected representative; or as having an external or internal focus (Mouritzen and Svara 2002; Karlsson 2013b; Sansom et al. 2013; Grant et al. 2014). Further, as policymakers have increasingly turned to strengthening leadership arrangements at the local level as a way to enhance the performance of local government (see, for example Sansom 2012; Martin and Aulich 2012) scholarly attention has focused on the issue of power relations and 'leadership at the apex' of local government (Mouritzen and Svara 2002). 
Various approaches have been deployed to examine both the legislatively inscribed relationships and informal interactions between councillors and senior staff and among councillors themselves. For example, there have been analyses of the efficacy (or otherwise) of particular institutional arrangements, especially the ideal role of the mayor in local governments (see, for example, Sansom 2012; Grant et al. 2014). Another focus has been the relationship between elected and appointed officials. Drawing on a comparison of executive relations in 14 countries including Australia, and using a range of statistical techniques, Mouritzen and Svara (2002) examined what they referred to as the 'constitutions' of local government. They identified four ideal types of local governmental arrangements. First, the strong mayor form, wherein the elected mayor controls the elected council and is in charge of all executive functions. Second, the committee leader form, that sees the political leader, who may or may not be called the mayor, share executive powers with collegiate bodies (e.g. standing committees) and with the chief executive officer (CEO). Third, the collective form, in which an executive committee makes all executive decisions. Fourth, the council manager form, which most accurately describes the overwhelming majority of local governments in Australia. In this case all executive functions are in the hands of a professional administrator, the CEO, who is appointed by the council.

Other studies have adopted a broadly qualitative approach to the study of local authorities and local power, conducting in-depth interviews with a range of participants from the local level (see, for example, Hutchinson et al. 2014; Smith-Ruig et al. 2016; Martin and Aulich 2012; Bochel and Bochel 2010; Ryan et al. 2000). However, to date little attention has been given to how the intended directions of Australian reforms ${ }^{1}$ - especially the pursuit of efficiency, effectiveness and community engagement through strategic and corporate planning - interact with frameworks for political and community governance. In this article we examine the way councillors understand their roles and whether their understandings coincide with the role prescribed under the auspices of reform, in particular those informed by New Public Management (NPM) approaches. This article builds on a research project funded by the Australian Centre of Excellence for Local Government examining the changing nature of representation within the Australian context (see for example, Tan 2013; Tan and Grant 2013). It also draws on a paper presented at the 2014 International Research Society for Public Management conference (see Tan 2014). The article focuses on councillors in the state of Victoria, Australia. Initially, we adopt an 'institutional approach', examining the legislative framework within which local governments operate. According to this method, while it is recognised that "political institutions do not determine the behaviour of political actors", at the same time it is acknowledged that they "shape political behaviour by providing a relatively systematic and stable set of

\footnotetext{
${ }^{1}$ This is in contrast to the extensive examination of local government reform in the UK. For example, Laffin (2008) provided an extensive overview of the 'Local Government Modernisation Agenda', such as the reforms providing officers with a "new set of arguments for the primacy of management: and therefore the importance of role of the CEO" (Laffin 2008, p. 115).
} 
opportunities and constraints", or "enforced prescriptions" of behaviour (Lowndes and Leach 2004, p. 560). In the case of Victoria the reforms to the Local Government Act 1989 (Victoria) prescribe that councillors should focus on strategy and policymaking and not be involved in the day-to-day administration of councils.

The analysis of the legislative framework is then augmented by data drawn from 17 semi-structured in-depth interviews with councillors and two focus group discussions. The main aim of the interviews and focus groups was to examine councillors' understandings of their roles. They indicated that there is a considerable discrepancy between the prescribed roles of councillors under the Local Government Act 1989 (Victoria) - which has been significantly amended over time - and how councillors perceive the ambit of their authority and their roles.

By way of introduction we commence with a brief overview of NPM as a mode of reform to government generally and to Australian local government in particular, specifying how it has been introduced to various local government acts generally and in Victoria in particular. We then examine the setting for the study, local government in the state of Victoria. We go on to specify the methodology of the qualitative element of the research, exploring the diversity of understandings councillors have of their roles, their views on the optimal level of professionalisation of their offices, the influence of the number of councillors and their views concerning representation of their constituents. We conclude by exploring the implications of our findings for local government practice and for future research.

\section{New Public Management}

It is possible that any discussion of the contemporary pervasiveness of New Public Management (NPM) will be viewed as anachronistic. In both the theory and practice of public administration, NPM has been, if not superseded, at least significantly augmented by 'public value management' or the 'paradigm' of public value creation (see, for example, Stoker 2006; O'Flynn and Alford 2008). However, as will be demonstrated with respect to the particular context examined in this article, the lasting impact of NPM can be seen in the relatively stable legislative frameworks that, while subject to incremental change, for the most part have evolved in the specific direction of NPM over time.

As described by Orr (2005, p. 375), the "New Public Management discourse...suggested that bureaucrats and producers had too much power and, as they were protected from market disciplines, were consequently unresponsive to the needs of consumers". In his concise yet comprehensive account, Diefenbach (2009) provided a systematic and insightful survey of NPM, distilling five basic assumptions and core elements as outlined in Table 1. 
Table 1: Basic assumptions and core elements of New Public Management

\begin{tabular}{|c|c|}
\hline Area & Element \\
\hline $\begin{array}{l}\text { 1. Business environment } \\
\text { and strategic objectives }\end{array}$ & $\begin{array}{l}\text { - assumption of strong external pressure, of a much more challenging and } \\
\text { changing business environment } \\
\text { - conclusion that there is a need for a new strategy and that there is no alternative } \\
\text { for the organisation but to change according to larger trends and forces } \\
\text { - market-orientation: commodification of services under the slogan of 'value for } \\
\text { money' } \\
\text { - stakeholder-orientation: meeting the objectives and policies of strong and } \\
\text { influential external stakeholders } \\
\text { - customer orientation: service delivery from a customer's perspective } \\
\text { - increased organisational efficiency, effectiveness and productivity defined and } \\
\text { measured in technological terms } \\
\text { - cost-reduction, downsizing, competitive tendering, outsourcing, privatisation of } \\
\text { services }\end{array}$ \\
\hline $\begin{array}{l}\text { 2. Organisational } \\
\text { structures and processes }\end{array}$ & $\begin{array}{l}\text { - decentralisation and re-organisation of organisational units, more flexible } \\
\text { structures, less hierarchy } \\
\text { - concentration on processes, that is, intensification of internal cross boundary } \\
\text { collaboration, faster decision-making processes and putting things into action } \\
\text { - standardisation and formalisation of strategic and operational management } \\
\text { through widely accepted management concepts }\end{array}$ \\
\hline $\begin{array}{l}\text { 3. Performance } \\
\text { management and } \\
\text { measurement systems }\end{array}$ & $\begin{array}{l}\text { - systematic regular and comprehensive capturing, measurement, monitoring and } \\
\text { assessment of crucial aspects of organisational and individual performance } \\
\text { through explicit targets, standards, performance indicators, measurement and } \\
\text { control systems. } \\
\text { - positive consequences for the people working with and under such systems such } \\
\text { as increased efficiency, productivity and quality, higher performance and } \\
\text { motivation }\end{array}$ \\
\hline $\begin{array}{l}\text { 4. Management and } \\
\text { managers }\end{array}$ & $\begin{array}{l}\text { - establishment of a 'management culture': management is defined as a separate } \\
\text { and distinct organisational function, creation of (new types of) managerial posts } \\
\text { and positions, emphasising the primacy of management compared to all other } \\
\text { activities and competencies } \\
\text { - 'managers' are defined as the only group and individuals who carry out } \\
\text { managerial functions }\end{array}$ \\
\hline $\begin{array}{l}\text { 5. Employees and } \\
\text { corporate culture }\end{array}$ & $\begin{array}{l}\text { - empowerment and subsidiarity, staff are expected to develop 'business-like' if not } \\
\text { entrepreneurial, attitudes } \\
\text { - idea of leadership and a new corporate culture }\end{array}$ \\
\hline
\end{tabular}

Source: Adapted from Diefenbach (2009, p. 894)

Examining Table 1, while the key features listed in the left hand column, including inter alia changes to organisational structures and processes, elements of performance management and changes to employees' conditions are important to note, what is of more interest is Diefenbach's (2009) characterisations of particular elements of organisations influenced by NPM. Thus, not only is the area of reform toward a "business environment and strategic objectives" characterised by "customer orientation" and "increased organisational efficiency", for Diefenbach $(2009$, p. 894) this also entails "the assumption of strong external pressure, of a much more challenging and changing business environment" (emphasis added). Similarly with respect to "employees and corporate culture", Diefenbach (2009, p. 894) argued that "empowerment and subsidiarity" are ascribed to individual 
units of government service delivery, such that "business-like, if not entrepreneurial approaches" are key features of the NPM approach.

While all elements discussed by Diefenbach (2009) are relevant to a discussion of local government reform, the emphasis upon business-like approaches and strategic objectives, coupled with the establishment of management and managers 'as a separate and distinct organisational function' (see Table 1) are, arguably, the aspects of NPM which have had the strongest impact upon the role of councillors in Australia. Krapp et al. (2013) examined NPM in the context of local government, arguing that NPM reforms pose a fundamental question about the function of local councillors, who are now required to focus on strategic objectives and desist from interfering in operations. They also argued that while councillors' roles may change under NPM, at the same time they ought to expect better performance from local government administrations. Ideally, this is achieved by elected members assigning the necessary responsibilities and resources to competent managers so as to ensure that agreed objectives are achieved. Further, structures to monitor progress are established, such as budget monitoring and performance measurement systems to enable politicians and citizens to evaluate the performance of the administration (Krapp et al. 2013, p. 224). In the UK, Rao (2006) explained that reforms to modernise the local government sector often involved greater delegation of powers to officers (i.e. staff) and that councillors were often opposed to delegating any of their powers to officers.

In Australia the local government policy context has evolved significantly over the last three decades reflecting the introduction of NPM, which, it was argued, would improve efficiency and streamline the delivery of services (Baker 2003; Marshall 2003; Aulich, 2005). Local government reforms implemented in Australia from 1985 to 2005 have reshaped the municipal landscape (Marshall 2008). This was achieved in two main ways. First, widespread programmes of council amalgamations were undertaken across state jurisdictions except Western Australia, reaching a peak during the 1990s when the number of councils nation-wide decreased from 866 to 626 . In Victoria the amalgamation process was especially dramatic. In January 1993 there were 210 local government councils and by December 1995 there were 78, a decline of 73\% in three years (Grant et al. 2009). Second, substantial organisational and managerial restructuring, premised on a rethinking of the functions of local government and councillors were implemented. This was reflected in the introduction of corporate management systems for local governments including cost-accrual accounting and the restructuring of reporting lines away from the 'town clerk' model to embrace divisional and sectional management structures (Marshall 2003, 2008). NPM principles also affected the management of councils and introduced a de jure clear delineation of responsibilities between elected and appointed staff. Of all the jurisdictions Victoria probably adopted the most radical approach to managerial reform, introducing compulsory competitive tendering, the separation of purchaser-provider functions (see, for example, Ryan et al. 2000) and the extensive privatisation of utilities (Marshall 2008). 
In contrast to most accounts of the reasons for the implementation of amalgamation programmes, Baker (2003) linked the compulsory consolidation of councils in Victoria to the need for larger administrative structures so that NPM reforms could be introduced and management pivoted away from its traditional base in professional associations (engineering, town planning, for example) to a discrete managerial layer within the sector. Otherwise, stated structural reform and NPM-style administrative reforms were heavily linked rather than being justified separately.

In this model the role of councillors was re-envisaged. No longer were councillors expected to be involved in the day-to-day running of their councils. This was to be left to appointed 'experts'. Councillors were now expected to focus on strategic decision-making. As Pierre (1999, p. 9) explained, NPM approaches assume that service producers operate at an arm's-length distance from elected officials. Their main role is confined to defining long-term objectives for service production. Service production is to be guided via direct, market-like communication between producers and customers. Newnham and Winston (1997, p. 106) contend that the redefinition of the role and function of councillors is in fact necessary under NPM because of the requirements to distinguish between policymaking and administration. They also argue, perhaps more importantly, that the complexity and professionalism of modern management has become such that most councillors have neither the background nor qualifications required. Ideally, the removal of these responsibilities enables councillors to concentrate on policy direction and strategic planning for the municipality.

In Australian local government key elements of NPM have been implemented. For example, the Local Government Act 1989 (Victoria) now states that the role of a council includes "providing leadership by establishing key strategic objectives and monitoring their achievement" (s. 3D, 2B). It is important to note that this incorporation of NPM principles has been incremental in that particular jurisdiction. For example, the latter stipulation was introduced in 2003 with the passing of the Local Government (Democratic Reform) Act 2003. In 1997, some eight years after the introduction of the Local Government Act 1989 (Victoria), the powers of the CEO were explicitly expanded to include, inter alia "appointing as many staff members as are required to enable the function of the council to be carried out" (s. 94A, 2). The implementation of NPM-inspired legislation culminated in the Local Government Amendment (Performance Reporting and Accountability) Act 2014. This Act requires that councils implement a finely-granulated system for reporting against a series of performance indicators. In this way, the broad tenants of NPM as discussed by Diefenbach (2009) have been gradually introduced to enforce roles and behaviour across the Victorian local government sector.

There has been a similar trend in other Australian jurisdictions. In New South Wales the Local Government Act 1993 now specifies that the role of a councillor is inter alia to provide civic leadership in guiding the development of the ten-year community strategic plan and to review the 
performance of the council (s. 232). ${ }^{2}$ In Queensland, s. 12 of the Local Government Act 2009 states that all councillors are responsible for ensuring that local governments achieve their corporate plans. Although these changes to Australian local government have been documented (Aulich 2005; Marshall 2008) and the changes in the relationship between elected and appointed officials have been examined (Martin and Aulich 2012; Grant et al. 2014), the overwhelming preoccupation of researchers in the Australian local government context continues to be with assessing the resultant change in operational efficiencies and long-term financial sustainability of local governments (see, for example, Dollery et al. 2013; IPART 2015). In this article we are specifically concerned with how councillors perceive their role and whether this coincides with the role of councillors prescribed under the auspices of NPM reforms. It is to these questions in the context of the particular jurisdiction of Victoria that we now turn.

\section{The research setting: local government in Victoria}

The state of Victoria is $237,629 \mathrm{~km}^{2}$ (comprising 3\% of the Australian land area) and in June 2013 the population was 5,737,600 (Australian Bureau of Statistics 2013). It is divided into 78 local government areas (LGAs) and there are a total of 630 councillors (Municipal Association of Victoria 2013). Approximately $74 \%$ of Victoria's population lives in greater Melbourne, the second largest city in Australia (Australian Bureau of Statistics 2013). The constitutional arrangements of local government in Victoria are not uniform. LGAs are either 'unitary' for voting purposes or alternatively are subdivided into wards, with one or several councillors elected to represent a smaller area within the LGA. The majority of councils in Victoria have multi-member wards (i.e. with two or more councillors being elected to represent a smaller area within the local government boundary), followed in descending order by unsubdivided councils (local government areas without wards), those with a combination of multi- and single-member wards and local governments with single-member wards only, as presented in Table 2.

\footnotetext{
${ }^{2}$ It is difficult to overstate the radical nature of reforms to leadership roles entailed in the rewriting of the local government acts across Australian jurisdictions. While in the case of Victoria the reforms to leadership were introduced incrementally under various legislative adjustments (as discussed above) other jurisdictions adopted a more vigorous approach to reforms. For example, under the current legislation in NSW the role of the mayor is limited to "exercising, in cases of necessity, the policy-making functions of the governing body of the council; to exercise such other functions as the council determines; to preside at meeting of the council and to carry out the civic and ceremonial functions of the mayoral office" (s. 226; see Local Government Act 1993 [NSW]). Prior to the introduction of the Local Government Act 1993 (NSW) the mayor had two roles:
}

One role makes him or her 'first citizen' representing the local authority on all formal occasions and taking the lead in official functions... The second is the more powerful role of chief executive. According to the decision of each individual council, this role may be purely a titular in function or may have conferred upon the mayor complete control over the day-to-day running of the council (Bains and Miles 1981, p. 149).

The redrafting of the Act in 1993 stripped the mayor of the CEO role such that their functions fall squarely within the NPM approach, separating political leadership from the administration of public sector organisations. 
Table 2: Victorian local government constitutional arrangements

\begin{tabular}{|l|c|c|}
\hline Constitutional Arrangement & Number of Councils & Percentage \\
\hline Multi-member wards & 32 & $41 \%$ \\
\hline Unsubdivided & 22 & $28 \%$ \\
\hline Mixed, single- and multi-member wards & 13 & $17 \%$ \\
\hline Single-member wards & 11 & $14 \%$ \\
\hline Total & 78 & $100 \%$ \\
\hline
\end{tabular}

Source: based on Victorian Electoral Commission (2013)

In 2013 the Municipal Association of Victoria (MAV) published a profile of Victorian councillors. In line with the European experience (Egner et al. 2013), the majority of elected representatives were married, male and 56-65 years-old was the median age group. A majority were born in Australia; however for more than $30 \%$ at least one parent was born overseas. The majority of councillors reported being 'managers' or 'professionals' (73\% of the sample) with post-school qualifications and were working in the private sector or were self-employed. In terms of political allegiances, $23 \%$ of councillors stated that they identified with no political party or were self-declared 'swing' voters, approximately 28\% identified as Liberal (the conservative party in Australia), 21\% as Labour and 15\% listed their political preference as 'other party/independent' (MAV 2013).

\section{Methodology}

The study draws on 17 semi-structured interviews and two focus groups. Twelve councillors were interviewed alongside five senior local government staff (CEOs and directors). The interviewees were drawn from 18 councils in Victoria. Senior staff were interviewed to provide a different, yet informed perspective of the effects of local government reform on the role of councillors. The research was carried out in partnership with the Victorian Local Governance Association (VLGA). The VLGA notified their members of the research and asked for expressions of interest from councils to participate. Interviewees and the focus group participants volunteered to participate in the study. The councils in the sample group represent a wide range in terms of size, geographical location (rural, regional and metropolitan) and population. This allowed us to obtain a diversity of experiences and viewpoints. Due to the geographical distances involved, the interviews were carried out by telephone and were approximately thirty to forty-five minutes in duration. The interviewees are profiled in Table 3: 
Table 3: Profile of councils represented in the interviews

\begin{tabular}{|c|c|c|c|c|}
\hline Interview & $\begin{array}{l}\text { Type of } \\
\text { council }^{*}\end{array}$ & Structure & $\begin{array}{l}\text { Number of } \\
\text { elected } \\
\text { members }\end{array}$ & Elected member or staff \\
\hline 1 & RAV & Unsubdivided & 7 & Elected member \\
\hline 2 & URM & Unsubdivided & 9 & Elected member \\
\hline 3 & URM & Unsubdivided & 7 & Elected member \\
\hline 4 & UFL & Multi-member wards & 11 & Staff \\
\hline 5 & URM & Multi-member wards & 9 & Elected member \\
\hline 6 & UFS & Single-member wards & 7 & Elected member \\
\hline 7 Focus Group & $\begin{array}{l}\text { URS } \\
\text { RSG } \\
\text { URV }\end{array}$ & $\begin{array}{l}\text { Unsubdivided } \\
\text { Multi-member ward } \\
\text { Single-member wards }\end{array}$ & $\begin{array}{r}7 \\
9 \\
12 \\
\end{array}$ & $\begin{array}{l}\text { Elected members and } \\
\text { staff }\end{array}$ \\
\hline 8 & URL & Multi-member ward & 9 & Elected member \\
\hline 9 & UFM & Single-member ward & 7 & Elected member \\
\hline 10 & RAL & Multi-member & 7 & Elected member \\
\hline 11 & RAV & Unsubdivided & 7 & Elected member \\
\hline 12 & UDM & Multi-member ward & 7 & Elected member \\
\hline 13 & RAV & Unsubdivided & 7 & Elected member \\
\hline 14 & UDL & Multi-member ward & 7 & Staff \\
\hline 15 & URM & Multi-member ward & 9 & Staff \\
\hline 16 & URS & Unsubdivided & 7 & Elected member \\
\hline 17 & UFM & Multi-member ward & 7 & Staff \\
\hline 18 Focus Group & $\begin{array}{l}\text { UFM } \\
\text { UDV }\end{array}$ & $\begin{array}{l}\text { Multi-member ward } \\
\text { Multi-member ward }\end{array}$ & $\begin{array}{l}9 \\
9\end{array}$ & Elected members \\
\hline 19 & URL & Multi- and single-member wards & 9 & Staff \\
\hline
\end{tabular}

Key: RAL - Rural Agricultural Large; RAV - Rural Agricultural Very Large; RSG - Rural Significant Growth; UDL - Urban Development Large; UDM - Urban Development Medium; UDV - Urban Development Very Large; URM - Urban Regional Medium; URS - Urban Regional Small; UFL- Urban Fringe Large; UFM Urban Fringe Medium; UFS - Urban Fringe Small; URL - Urban Regional Large; URS - Urban Regional Small; URV - Urban Regional Very Large.

Source: Department of Infrastructure and Regional Development (2013)

The focus groups were constituted by locally elected representatives in the metropolitan areas of Melbourne (four participants) and Geelong (six participants). This purposively selected sample size and qualitative methodology broadly conforms to other work examining both elected and appointed executive roles in local government (see, for example, Bochel and Bochel 2010).

The semi-structured interviews and focus groups were organised around a set of themes that together sought to address the broad topic of local representation and how councillors perceived their role. The interviews and focus groups concentrated on the following themes: The strengths and weaknesses of the various local government structures; the role and election of mayors and deputy mayors; the perceived roles of councillors; how they perceived local representation and the issue of remuneration of councillors. The interview data were codified and analysed in accordance with these themes. In this article we focus on interviewees' understandings of the role of the councillor and councillors' perceptions of local representation. 


\section{How councillors perceive their role}

The discussion concerning the role of a councillor is important because NPM is predicated on councillors taking a strategic and policymaking role and staying out of the day-to-day management of the organisation (Pierre 1999, p. 9) as has been clearly stipulated by successive amendments to the Local Government Act 1989 (Victoria) described above. However, the practice of local representation is complex. As Sweeting and Copus (2012, p. 22) explained, there are "tensions inherent in the role of councillors which include different sorts of relationships with citizens and parties, the concern with both local responsiveness and national priorities and the political and managerial roles that councillors assume". This section explores the understandings of locally elected representatives with regard to their role in order to compare these understandings with the objectives of local government reforms.

\section{Diversity of understanding of councillor roles}

Councillor roles are not generic across different systems, nor static in the face of reform (Egner et al. 2013, p. 13). While there is agreement that a fundamental aspect of politics is about managing conflicts of interests between groups and individuals, there is no consensus about how political representation should be interpreted and no right answer regarding which groups or interests a representative ought to prioritise. To a certain extent, and despite the influence of legislative requirements as emphasised above, each representative has the space to determine how they see their role and to act accordingly.

This was reflected in the interviews and focus groups. There was a range of positions as to what role councillors thought they should play and the legislation setting out the de jure role of a councillor often had little or no bearing on their views or actions. As one councillor from a large council commented:

How councillors execute their role is based on the individual... Some spend a lot of time helping residents navigate council bureaucracy while others focus on strategy and policy (interviewee 15).

Some councillors understood their role strategically, in the sense conveyed by the NPM reforms. For example, interviewee 2 commented:

The role of a councillor is to set directions. They are close enough to the community to know what is needed.

Similarly interviewee 15 stated:

The councillor's role is to ensure that policy and strategic decision-making reflect community expectations.

Alternatively, some councillors focused on their responsibility to help the community negotiate local government procedures:

Councillors ... translate shire processes for the community especially with regard to planning and building matters, easing people through these processes (interviewee 5). 
The role of councillors in the oversight of council expenditure was also highlighted:

We don't want to burden the residents with rates that are too high. A councillor needs to ensure value for money (interviewee 8).

This range of views of the role of the councillor from setting strategic directions, to helping the community to navigate organisational bureaucracies and to providing oversight and scrutiny of council expenditure is noteworthy. It indicates that there is no consensus as to what the role of the councillor should be and that the role of the councillor as envisaged by local government reform premised on a NPM approach has had a limited impact.

In addition, this range of views may also reflect ambiguity in the legislation, particularly when taking into account its incrementally evolving nature over time. As we have seen, the Local Government Act 1989 (Victoria) states that the role of a council includes: "acting as a representative government by taking into account the diverse needs of the local community in decision-making" (s. 3D, 2a). In their review of local government in another Australian state, New South Wales (NSW), Sansom et al. (2013, p. 61) explained that under s. 232 of the Local Government Act 1993 (NSW) the role of a councillor is divided into two parts: as a "member of the governing body" and as an "elected person". The former is seen as deliberative - planning, resource allocation, policy development and performance monitoring. These functions align with councillors performing and behaving as a 'board of directors'. The role of a councillor as an elected person includes community representation, leadership and communication. These are more clearly representative functions and encompass what most councillors would regard as a central part of their job and fundamental to being re-elected (Sansom et al. 2013).

The interviews indicated that the role of 'trustee' most closely aligned with councillors' understanding of their role and mode of operating. A trustee votes according to their own convictions, rather than seeking to 'mirror' the wishes of the constituents themselves (see, for example, Grant et al. 2014, p. 6; Karlsson 2013b). Elected members act on the premise that they have been given a personal responsibility by the voters to make decisions drawing on their own judgement (Karlsson 2013b). Several councillors stated that they used their own judgement to make informed decisions:

When it comes to making decisions councillors use their own judgement based on their interactions with the community, on good information and on a knowledge of the relevant legislation (focus group 1 ).

This was achieved through talking with their constituents, considering the relevant information provided to them by staff and using their own knowledge in order to take a considered viewpoint on an issue (interviewees 3 and 10; focus group 1): "By electing us, the community has said that they value our judgement" (interviewee 10). This finding is broadly in line with Karlsson's (2013b, pp. 98-100) analysis of councillors' perceptions. He found that the most common understanding of representation expressed by councillors is the trustee ( $57 \%$ of respondents). 
Representation as a trustee aligns well with councillors taking a strategic role in governing their communities and with the NPM approach which, generally speaking, likens the elected decisionmaking body to a board of directors. This was expressed clearly by interviewee 3:

Councillors in this local government function as a board of directors. They set the direction of the council and try not to get involved in operations. They stay out of the detail.

However, although many of the councillors saw themselves as trustees in terms of representation, only two of the 17 interviewees saw themselves in a strategic role as members of a board of directors. One councillor (interviewee 9) from a smaller rural shire commented:

Councillors do not have enough power and are hamstrung by the advice that they are given by officers [local government staff].

In her opinion councillors should have more power to act on behalf of residents. This councillor gave the example of a resident in dispute with the council administration over the cutting down of a tree, with the councillor feeling that elected officials rather than staff should have the power to make decisions in this regard.

These opposing points of view illustrate the differences between taking a strategic or policymaking view of the role of a councillor on the one hand in contrast to one that expects elected members to be involved in day-to-day decision-making. The current reform processes, which have been in place for over 20 years, emphasise the importance of the strategic decision-making role of the councillor over involvement in operational issues. However, our qualitative research clearly illustrated that many councillors continue to feel that it is essential to be involved in the day-to-day running of the council.

\section{Councillors as 'laymen' or professionals?}

One aspect that has the potential to shape how councillors understand their role is whether they are perceived as 'laymen' carrying out their representative roles on a voluntary part-time capacity, or alternatively as 'professionals' who are remunerated and expected to carry out their duties on a fulltime basis (see, for example, Dollery and Grant 2011, p. 11). In the Australian context the legislatively inscribed role of councillors as either laymen or as professionals differs by jurisdiction. In the state of Queensland locally elected members are expected to dedicate their time and expertise on a full-time basis and receive a commensurate payment. In Victoria, however, councillors are expected to fulfil their position on a voluntary basis and are paid a moderate allowance (Tan 2013, p. 27). These differences have a bearing on the kinds of citizens who are able to or are interested in standing for election and influence how councillors perceive their role. Most of the interviewees recognised that the low allowances may be a barrier to attracting a more diverse range of local government candidates:

The net allowance for councillors and a low mayoral allowance are insufficient to attract younger people and single parents and highly skilled people (interviewee 2). 
Similarly:

If they [the allowances] stay at the same level, the current demographic/age group of councillors will remain the same regardless of any programmes put into place (interviewee 2).

As otherwise stated, the demographic cohort from which councillors are drawn may have a particular view about the way that representation ought to function.

However, some caution was expressed about advocating for an increase in allowances. A participant in focus group 2 commented that "locally elected members need to be community-minded", and there was concern that if the positions were paid too much it would attract the 'wrong' kind of people. As such, whether a state's local government act prescribes a full-time paid role or voluntary part-time role to councillors is relevant to this discussion. It has a bearing on the kinds of citizens that are able to run for office, how the community views councillors and how local representation is carried out. Because this study was limited to Victoria it was not possible to determine whether full-time paid councillors have a different view of their role in comparison to part-time voluntary elected members.

\section{Influence of the number of councillors}

The number of councillors representing an area has the potential to impact on how councillors see their role. A local government's constitutional arrangement is the framework that de jure defines a councillor's function. These arrangements regulate the political sphere providing clear limitations in some areas while leaving room for individual discretion in others. This also means that the interpretations of representatives may be changed by means of institutional reforms (De Groot et al. 2010). Political systems are based on political institutions, i.e. a 'constitutional setting', which guides and limits the actions of the actors within the system:

Situated in a political system, actors will consider the 'lay of the land', adapt their notions about what the appropriate conduct is for actors like themselves in this environment and then, as a consequence, adjust their behaviour (Karlsson 2013a, p. 681).

This constitutional framework is therefore an important element influencing councillor behaviour and their understanding of their role. The Local Government Act 1989 (Victoria) sets out this particular institutional framework. It states that:

- councils may have between five and 12 elected members

- local governments may be divided or undivided (i.e. have single-member or multi-member wards)

- the variation of representation ratios among wards within a council area should be no greater than $10 \%$

- a mayor be elected from among the councillors (except in the cases of Melbourne and Geelong). 
The number of elected representatives on a council may also have a bearing on their understanding, and implementation of their role. For example, several of the metropolitan local government areas of Victoria are experiencing population growth which might result in an increase in councillor numbers. According to participants in both interviews and focus groups undertaken for this article, an increase in the number of councillors may have a significant impact on the way a council functions and how councillors see their role. An interviewee from a local government where the number of councillors had increased from nine to 11 , explained:

This [increase] has meant a change in the way the group functions and group dynamics... Councillors have had to think more carefully about their roles and the organisation has had to respond to the growing interest in councillors not just being a generalist on issues but allowing councillors to get involved in issues and with the community in more depth.

Elected members in this particular council moved from being generalists to becoming more closely involved in particular areas with the result that they moved to a portfolio system (interviewee 4). For example, some may choose to concentrate on sport and leisure infrastructure and services; others on the provision of community services such as child-care and others on matters related to land use planning.

The majority of the local governments in Victoria have either seven or nine elected members. A seven-member council can pose a particular challenge in the Victorian context where the mayor is elected by councillors for one year within the council's four-year term. Several interviewees, both senior staff and councillors, highlighted this issue. For example a councillor from a metropolitan council commented:

In [our] council the election of the mayor was pre-planned. There is a flaw in the election of the mayor by councillors when there are seven elected members in that four can decide among themselves who will be mayor and the remaining three have no say in the matter (interviewee 9).

What can happen is a split among councillors, where a majority of elected members work together to make decisions and share the mayoral role. Although this phenomenon was discussed particularly in the context of a seven-member council, this division of elected members can occur in other configurations, for example, a block of six elected members on a council of eleven can work together to determine the mayoralty and control decision-making. While the mayor does not have more power than the other councillors, the position does attract a full-time allowance and fulfils a ceremonial role.

What is unclear is the impact of the development of these kinds of allegiances and factions on councillors' understanding of representation and how they carry out their decision-making responsibilities. Thus, in the Victorian example there is the possibility that the structure of local representation (particularly the election of the mayor by councillors) affects councillors' understanding of their role and how they behave. Rather than thinking strategically in terms of the governance of communities they are thinking strategically in terms of political alliances and 
influence. The election of mayors by councillors can result in elected members voting on issues in line with political allegiances rather than in the interests of their constituents.

\section{Councillors' views of representation}

When interviewees were asked how they represented their communities and the role of councillors in this regard, there were a range of views. All of the elected representatives said that their job was to represent their constituents, wards or communities but there was variation in their conceptions of what this representation entailed. Some commented that their main task was ensuring that residents receive adequate service delivery or value for money from their council:

We don't want to burden residents with rates that are too high; a councillor needs to ensure value for money (interviewee 8).

The notion that a primary task should be to increase citizen participation was not part of this particular interviewee's framework. Some interviewees saw themselves more as a 'Board of Directors', making strategic and long-term decisions:

The councillor's role is to ensure that policy and strategic decision-making reflect community expectations... Councillors set the strategic and policy direction of the organisation (interviewee 15).

Most of the interviewees viewed consultation with the community in decision-making as a central part of their role. For example, a participant in focus group 1 stated, "[i]t is important for councillors to consult with residents". Interviewee 13 echoed this view: "You have to be a good listener to be a councillor".

There was consensus that in order to adequately represent their communities councillors need to understand the views and wants of residents:

A councillor should consult as much as possible to make sure they understand the interests of the community (interviewee 8).

A councillor represents the community ... They identify the needs of residents and push for those needs to be met (interviewee 13).

The importance of informed decision-making was raised by interviewees. Informed decision-making requires adequate consultation with the community so that councillors have the knowledge required to make decisions that are in line with the desires of their constituents. However, several councillors noted that there were instances where residents may not have the required understanding of an issue or of 'the big picture' in order to make informed decisions.

Only three councillors from the total of 17 interviewees emphasised their oversight role. It was argued that elected members should:

Play a scrutiny role, questioning how things are done in the organisation and whether a particular programme or activity is the right thing to spend money on over another priority (interviewee 5). 
In a similar vein, it was acknowledged that councillors also have a role in assuring service delivery and value for money. This is in line with the observation by Krapp et al. (2013) concerning the importance of the monitoring role of elected members under NPM reforms. The emphasis on the need for councillors to understand the aspirations of their communities and provide monitoring or scrutiny of the organisation is compatible with a strategic function for elected members. However, as illustrated, the councillors interviewed felt that their role encompassed a broader range of responsibilities. In addition to their oversight role during the interviews councillors spoke of the need to engage with the community, to represent individual resident needs to staff, to be more involved in day-to-day decision-making.

The interviews indicated that the various legislative arrangements of local governments can influence whether councillors see themselves as representing the interests of the community as a whole. When discussing the relative merits of unsubdivided and subdivided councils, the four interviewees from unsubdivided councils felt that in local governments without wards there was a broader and more representative approach by councillors and councillors are more likely to govern for the whole of the local government area (interviewee 15). Arguably - and importantly for the introduction of NPM reforms - this arrangement enables councillors to take a more strategic view of governance. By contrast, where a local government has ward structures, councillors are more likely to govern in the best interests of their ward. Otherwise stated, one result of having subdivisions is that "councillors become a champion for their ward" (focus group 1). The division of local government areas into wards may therefore undermine the ability of elected members to function well as a board of directors.

The varied understandings of councillors' roles as regards to local representation is reflected in the literature that describes representation as sitting along two extremes of a continuum between collective versus individual interests. The 'corporate' view of representation claims that an elected member represents the interests of the whole community rather than a specific group of constituents (see for example, Grant et al. 2014). This view was articulated by many of the councillors interviewed. In contrast, the 'mirror' approach proposes that different representatives are spokespersons for different interests within the electorate (Karlsson 2013b, p. 101). Rather than taking a collective view, politics is the aggregation of interests and votes (see for example, Thomassen 2010). The interviewees did not hold this latter understanding of local representation. Heinelt (2013, p. 6) recently argued that in practice both concepts of representation complement each other. A vibrant and broader involvement of citizens and public deliberation in some phases of the policy cycle (such as identifying goals, setting agendas and implementation) can be compatible with the exclusive power of elected representatives to take final decisions of common interest. This discussion of councillors' views of representation is important because it demonstrates the wider remit that elected members fulfil beyond that of policymaking and setting strategic direction. 


\section{Concluding remarks}

Local government reform in Victoria and in Australia generally is being driven by a NPM perspective and the quest for a more financially sustainable sector. While this has important implications for the role of councillors, how councillors understand their roles has been a neglected area of research. This paper contrasted the changed prescribed roles for councillors under NPM-inspired reforms with councillors' understandings of their roles.

The research undertaken for this article emphasises that the introduction of NPM approaches and the associated structural changes to promote efficiency have aimed to shift the historical role of local government councillors. Councillors have been legislatively directed to move away from involvement in the day-to-day running of their councils and have been prescribed a more strategic function, identifying long-term goals and setting direction. However, the interviews and focus groups indicated that the reforms have not engendered the intended effect as to how councillors understand their roles. The NPM reforms have focused on the strategic policymaking roles of councillors while neglecting the broader community leadership aspects of the position. The research indicated that the way councillors understand their roles is not necessarily altered by legislative reforms. As stressed by Laffin (2008 pp. 120-121) "political modernisation illustrates an old lesson of administrative reform: while it is relatively easy to change organisational forms, the underlying institutional patterns usually prove less tractable".

Despite the limitations of the research conducted here in terms of the sample size of individual interviewees alongside two focus groups, it has demonstrated that there is a gap between the roles local government reforms prescribed for locally elected members and the actual practice of representation. The way the interviewees understood what representation involves does not concur with the local government reforms. It is also influenced by the particular institutional form of local government. As regards local representation the interviews and the focus groups suggest that some councillors have a corporate understanding of democracy and others are keen on broader forms of participation. However, many operate along a 'democratic continuum' at any given time to address particular circumstances or contexts. A better understanding of how they conceptualise their role and how they represent their community will inform efforts to improve the quality of local government. There is clearly room for further research in this regard, in particular that incorporating greater detail concerning individual participants from which qualitative data is derived. 


\section{References}

Aulich, C. (2005). Australia: Still a tale of Cinderella? In: Denters, B. and Rose, L. (eds) Comparing local governance: Trends and developments (pp. 193-210). London: Palgrave MacMillan.

Australian Bureau of Statistics. (2013) Australian demographic statistics, catalogue 3101.0. Available at: www.abs.gov.au/ausstats/abs@.nsf/mf/3101.0. [Accessed 4 May 2014].

Baines, M.A. and Miles, N.T.G. (1981) New South Wales. In: Power, J., Wettenhall, R. and Halligan, J. (eds) Local government systems of Australia. Advisory Council for Intergovernmental Relations Information Paper No. 7 (pp. 123-228). Canberra: Australian Government Printing Service.

Baker, G. (2003) Management reform in local government. In: Dollery, B., Marshall, N. and Worthington, A. (eds) Reshaping Australian local government: Finance, governance and reform (pp. 117-138). Sydney: Federation Press.

Barnett, N. (2011) Local government at the nexus? Local Government Studies, 37 (3), 275-290. doi: https://doi.org/10.1080/03003930.2011.571253

Beer, A., Morris, A. and Paris, C. (2014) Housing and local government in Australia in the $21^{\text {st }}$ century. Sydney: Australian Centre of Excellence for Local Government.

Bochel, H. and Bochel, C. (2010) Local leadership and the modernisation of local government. Local Government Studies, 36 (6), 723-737. doi: https://doi.org/10.1080/03003930.2010.523199

Brown, A.J. (2008) In pursuit of a 'genuine partnership': Local government and federal constitutional reform in Australia. University of New South Wales Law Journal, 31 (2), 435-466.

De Groot, M., Denters, B. and Klok, P.-J. (2010) Strengthening the councillor as a representative and scrutiniser: The effects of institutional change on councillors' role orientations in The Netherlands. Local Government Studies, 36 (3), 401-423. doi: https://doi.org/10.1080/03003931003730469

Department of Infrastructure and Regional Development. (2013) 2010-11 local government national report. Available at: http://www.regional.gov.au/local/publications/reports/2010_2011/LGNR2010-11.pdf [Accessed 6 May 2014].

Diefenbach, T. (2009) New public management in public sector organizations: The dark sides of managerialistic 'enlightenment'. Public Administration, 87 (4), 892-909. doi: https://doi.org/10.1111/j.14679299.2009.01766.x

Dollery, B.E. and Grant, B. (2011) Economic efficiency versus local democracy? An evaluation of structural change and local democracy in Australian local government. Journal of Interdisciplinary Economics, 23 (1), 1-20. doi: https://doi.org/10.1177/026010791102300101 and https://doi.org/10.1177/02601079X11002300102

Dollery, B.E., Kortt, M. and Grant, B. (2013) Funding the future: Financial sustainability and infrastructure finance in Australian local government. Sydney: Federation Press.

Dollery, B., O’Keefe, S. and Crase, L. (2009) State oversight models for Australian local government. Economic Papers, 28 (4), 279-290. doi: https://doi.org/10.1111/j.1759-3441.2010.00047.x

Dollery, B.E., Wallis, J. and Allan, P. (2006) The debate that had to happen but never did: The changing role of Australian local government. Australian Journal of Political Science, 41 (4), 553-567. doi: https://doi.org/10.1080/10361140600959775

Egner, B., Sweeting, D. and Klok, P.-J. (2013) Local councillors in comparative perspective. In: Egner, B., Sweeting, D. and Klok, P.-J. (eds) Local councillors in Europe (pp. 11-25). Springer: Wiesbaden. doi: https://doi.org/10.1007/978-3-658-01857-3, https://doi.org/10.1007/978-3-658-01857-3_14 and https://doi.org/10.1007/978-3-658-01857-3_1

Grant, B., Dollery, B.E. and Crase, L. (2009) The implications of the Lyons Report in England for structural reform in Australian local government. International Journal of Public Administration, 32 (10), 852867. doi: https://doi.org/10.1080/01900690903026034

Grant, B. and Dollery, B.E. (2012) Autonomy versus oversight in local government reform: The implications of 'home rule' for Australian local government. Australian Journal of Political Science, 47 (3), 99-214. doi: https://doi.org/10.1080/10361146.2012.704003 
Grant, B., Dollery, B.E. and Kortt, M. (2014) Recasting leadership in Australian local government reform: A typology from political theory. Local Government Studies, 40 (1), 1-21.

Heinelt, H. (2013) Councillors and democracy: What do they think, and how can differences in their views be explained? In: Egner, B., Sweeting D. and Klok, P.-J. (eds) Local councillors in Europe (pp. 85-96). Springer: Weisbaden.

Hutchinson, J., Walker, E. and McKenzi, F.H. (2014) Leadership in local government: 'No girls allowed'. Australian Journal of Public Administration, 73 (2), 181-91. doi: https://doi.org/10.1111/14678500.12075

IPART. (Independent Pricing and Regulatory Tribunal). (2015) Methodology for assessment of council fit for the future proposals. Local Government Consultation Paper. Available at: http://www.ipart.nsw.gov.au/

Karlsson, D. (2013a) The hidden constitutions: How informal political institutions affect the representation style of local councils. Local Government Studies, 39 (5), 681-702. doi: https://doi.org/10.1080/03003930.2012.670748

Karlsson, D. (2013b) Who do the local councillors of Europe represent? In: Egner, B., Sweeting, D. and Klok, P.-J. (eds) Local councillors in Europe (pp. 97-119). Springer: Weisbaden. doi: https://doi.org/10.1007/978-3-658-01857-3_6

Krapp, M.-C., Pleschberger, W., and Egner, B. (2013) Local councillors and administrative reforms. In: Egner, B., Sweeting, D. and Klok, P.-J. (eds) Local councillors in Europe (pp. 221-236). Springer: Weisbaden. doi: https://doi.org/10.1007/978-3-658-01857-3_12

Laffin, M. (2008) Local government modernistaion in England: A critical review of the LGMA evaluation studies. Local Government Studies, 34 (1), 109-125. doi: https://doi.org/10.1080/03003930701795014

Local Government Act 1989 (Victoria). Available at: http://www.austlii.edu.au/au/legis/vic/consol_act/lga1989182/

Local Government Act 1993 (New South Wales). Available at: http://www.austlii.edu.au/au/legis/nsw/consol_act/lga1993182/

Local Government Act 2009 (Queensland). Available at: http://www.austlii.edu.au/au/legis/qld/consol_act/lga2009182/

Lowndes, V. and Leach, S. (2004) Understanding local political leadership: Constitutions contexts and capabilities. Local Government Studies, 30 (4), 557-575. doi: https://doi.org/10.1080/0300393042000333863

Marshall, N. (2003) The roles and responsibilities of chief executive officers and councillors in Australian local government: A corporate governance perspective. In: Dollery, B., Marshall, N. and Worthington, A. (eds) Reshaping Australian local government: Finance, governance and reform (pp. 139-156): Sydney: Federation Press.

Marshall, N. (2008) Local government reforms in Australia. In: Dollery, B., Garcea, J. and LeSage, E.C. (eds) Local government reform: A comparative analysis of advanced Angl-American Countries (pp. 16-45). Cheltenham: Edward Elgar.

Martin, J. and Aulich, C. (2012) Political management in Australian local government: Exploring roles and relationships between mayors and CEOs. Sydney: Australian Centre of Excellence for Local Government, University of Technology, Sydney.

Mouritzen, P.E. and Svara, J.H. (2002) Leadership at the apex: politicians and administrators in Western local governments. Pittsburgh: University of Pittsburgh Press.

Municipal Association of Victoria. (2013) MAV councillor census. Victoria: MAV.

Newnham, L. and Winston, G. (1997) The role of councillors in a changing local government arena. In: Dollery, B.E. and Marshall, N.A. (eds) Australian local government: Reform and renewal. (pp. 105124). Macmillan Education, Melbourne.

O'Flynn, J. and Alford, J. (2008) The separation/specification dilemma in contracting: The local government experience in Victoria. Public Administration, 86 (1), 205-224. doi: https://doi.org/10.1111/j.14679299.2007.00708.x 
Orr, K. (2005) Interpreting narratives of local government change under the Conservatives and New Labour. British Journal of Politics and International Relations, 7 (3), 371-385. doi: https://doi.org/10.1111/j.1467-856X.2005.00173.x

Pierre, J. (1999) Models of urban governance the institutional dimension of urban politics. Urban Affairs Review, 34 (3), 372-396.doi: https://doi.org/10.1177/10780879922183988

Power, J., Wettenhall, R. and Halligan, J. (eds) (1981) Local government systems of Australia. Australian Council for Intergovernmental Relations (ACIR) Information Paper No. 7. Canberra: Australian Government Printing Service.

Rao, N. (2006) Modernising local government. Economic Affairs, 26 (1), 18-24. doi: https://doi.org/10.1111/j.1468-0270.2006.00607.x

Ryan, N., Parker, R. and Brown, K. (2000) Purchaser-provider split in a traditional public service environment: three case studies of managing change. Public Policy and Administration Journal, 9 (1), 206-221.

Sansom, G. (2009) Commonwealth of Australia. In: Steytler, N. (ed) Local government and metropolitan regions in federal systems (Vol. 6) (pp. 7-36). Montreal \& Kingston, London, Ithaca: McGill-Queens University Press.

Sansom, G. (2012) Australian mayors: What can and should they do? Sydney: Centre for Local Government, University of Technology.

Sansom, G., Munroe, J. and Inglis, G. (2013) Revitalising local government. Final Report of the NSW Independent Local Government Review Panel. Sydney: NSW Independent Local Government Review Panel.

Smith-Ruig, T., Grant, B. and Sheridan, A. (2016) Slow change at the top: 'Old hands' and 'accidental executives' in New South Wales local government. Australian Journal of Public Administration, 75 (1), 89-99. doi: https://doi.org/10.1111/1467-8500.12160

Stoker, G. (2006) Public value management: A new narrative for networked governance? American Review of Public Administration, 36 (1), 41-57. doi: https://doi.org/10.1177/0275074005282583

Sweeting, D. and Copus, C. (2012) Whatever happened to local democracy? The Policy Press, 40 (1), 21-38. doi: https://doi.org/10.1332/030557310x550123

Tan, S. (2014) The gap between institutional expectations and councillor perceptions of their roles: How serious can it be? International Research Society for Public Management Conference 2014, International Research Society for Public Management (IRSPM).

Tan, S.F. (2013) Issues in Australian local representation: A view from Victoria. Sydney: Australian Centre of Excellence for Local Government, University of Technology Sydney.

Tan, S.F. and Grant, B. (2013) Local representation in Australia: A review of the legislation and the literature. Sydney: Australian Centre of Excellence for Local Government, University of Technology Sydney.

Thomassen, L. (2010) Habermas: a guide for the perplexed. London: Continuum.

Victorian Electoral Commission. (2013) Report on the conduct of the 2012 local government elections. Victoria: Victorian Electoral Commission. 